\title{
5 \\ Building executive capacity in the Japanese Civil Service
}

\author{
Hiroko Kudo
}

The Japanese Civil Service faces many confronting issues as it grapples with the challenges of transforming a traditional Weberianstyle civil service into a modern, responsive and pro-active service. Traditionally, the Japanese Civil Service was characterised by its rigid career structures, elite hierarchies, aged cohorts of intakes, and a culture imbued with the importance of seniority. More recently it has been challenged with demands to modernise the service by placing greater emphasis on management, executive leadership, innovative thinking and problem-solving, promotion by merit, gender equity, and more open-minded 'participant centred' training. Although many influences on Japanese governance go back centuries, Japan in the postwar period has faced many social, demographic, economic and political challenges. Its population is declining and rapidly ageing, and after a postwar boom its economy has largely stagnated. Political change and uncertainty marked by a succession of very short-term government administrations have now become the norm, despite conservative governments led by the Liberal Democratic Party largely holding a hegemonic grip on power. Amidst the malaise of political volatility, Japan has made a number of attempts in recent decades to undertake administrative reforms along with some out-sourcing and down-sizing initiatives - often to become frustrated by the lack of implementation or political will to drive them. In recent years more 
extensive plans for fundamental cultural change in the civil service and changes to the recruitment and selection of staff have been announced which have more potential to modernise government administration and provide the necessary leadership and delivery capabilities for the future.

This chapter is in three parts. The first part outlines the current structure of the Japanese Civil Service, briefly describing its history, its main features and its present size. The second part describes the development of the current human resource development policies of the civil service, focusing on the training undertaken by the National Personnel Authority (NPA) and by other institutions. The third part explains the recent civil service reforms and focuses on two proposals by the NPA: one on recruitment and the selection system and the other on the civil service training system. The chapter concludes by addressing the most challenging question: how to sustain capacity while coping with the imperatives of changing competencies.

\section{Antecedents of the Japanese Civil Service}

The modern system of public administration in Japan was largely established in the late nineteenth century, after the Meiji Restoration in 1868. During this period, Japan's political, governmental and related public institutions were established based on models drawn from European counterparts. At the same time, Japan evolved its administrative systems and procedures to support such institutions. Daily practice in these organisations tended to preserve traditional Japanese values, with a formal set of procedures operating in tandem with powerful informal ones. Over this period, the Japanese public service enjoyed a good reputation and, indeed, contributed enormously to the nation's remarkable progress, combining traditional organisational values with the application of modern theories and techniques.

This situation changed drastically after World War II. Despite its strong reputation for efficiency, effectiveness, productivity and prestige, the Japanese bureaucracy was forced to change. Campaigns to reduce the size of government - in terms of both costs and staffresulted in the Japanese Government becoming the smallest among 
the industrialised democracies and having the fewest administrators relative to population size of any country in the Organisation for Economic Co-operation and Development (OECD).

After World War II, Japan started its dazzling climb as the world's 'economic miracle' (Clesse et al. 1997). One of the most popular explanations for this development is that power in Japan was centralised in the hands of 'Japan Inc.' - a ruling triad consisting of the elite of the bureaucracy, the ruling political party (the Liberal Democratic Party, LDP) and big business (Hayao 1993; Mishima 1998). ${ }^{1}$ According to this view, the bureaucracy was the key of the three actors, helped by its long traditions, prestige and expertise. The importance of the Japan Inc. view in creating this 'iron triangle' of administrative, political and economic elites has been used both to explain the 'economic miracle' of the 1960s and 1970s and to account for the present difficulties Japan faces in conducting systemic reform (Kerbo and McKinstry 1995; McVeigh 1998; Price 1997).

A cogent example of this view is provided by Curtis (1999), who focuses particularly on the '1955 regime' ${ }^{2}$ (see Stockwin 1997a, 1997b). Curtis suggests that the system was maintained by four mutually supporting pillars: 1) a broad public consensus to make Japan a leading global economic force; 2 ) the presence of large interest groups with close links to political parties; 3) total one-party dominance; and 4) a prestigious and powerful bureaucracy.

As the country moved from an industrial to a post-industrial economy, the interests of business, farmers and labour became more diverse and the Japan Inc. alliance weakened (Curtis 1999). ${ }^{3}$ Political representatives called $z o k u$, which literally means 'tribe', represented special interests. Zoku were members of the Japanese Parliamentusually from the dominant LDP - who specialised in a particular policy area and had close personal contacts with public servants in their corresponding ministries or bureaus. Hence, the 'iron triangle'

1 In this view, the ruling triad is united in promoting high economic growth above all else while at the same time subordinating Japan's defence and foreign policy more generally to that of the United States.

2 Also called the '1955 system'.

3 Curtis (1999: 44) describes it as 'a shift from interest group politics to the politics of special interests'. 
relations underpinning the Japan Inc. development model were reinforced at the level of these policy communities or sub-governments (Hayao 1993; Callon 1995).

Despite being a major player in these 'iron triangles', the bureaucracy was still perceived as a beacon of competency and integrity, safeguarding the national public interest against the short-sighted behaviour of politicians (Koh 1989; Curtis 1999). ${ }^{4}$ This reputation, however, was significantly eroded, particularly in the 1990s, by a number of widely criticised policy failures and high-profile scandals involving public servants.

Scandals and concerns about political corruption are certainly not new to Japan, with many such instances of varying degrees of seriousness (Curtis 1999). The important differences between Japan's most recent scandals and those in previous decades are that they now appear far more frequently and have more visibly involved bureaucrats (Stockwin 1997a, 1997b). One of the most prominent scandals in postwar Japan was the 1988 'recruit scandal', which involved 'insider stock' deals. The scandal claimed many top politicians; however, what was even more shocking to the public was the revelation that senior public servants were also involved.

The powerful Ministry of Finance was one of the institutions most affected by the scandals of the 1990s. For instance, in 1995 it was discovered that a high-ranking official in the ministry had failed to report to the tax authorities money he had received from donors (Hartcher 1998). In 1998, a former director-general of the ministry was arrested for leaking information in return for bribes. Then two of the ministry's bank inspectors were arrested for revealing information to several banks regarding the timing of upcoming inspections in return for expensive hospitality at restaurants, nightclubs and golf clubs. The decision of then prime minister, Ryutaro Hashimoto, to set up a committee that would eventually prepare the Ethics Law was a direct consequence of these scandals. However, the much publicised

4 Curtis (1999: 55) summarises the bureaucrats' position as follows: 'Recruited by competitive examination from among the best and the brightest graduates of Japan's most prestigious universities, especially from the Faculty of Law of the University of Tokyo, Japan's bureaucratic elite possessed high morale, a sense of mission, and a reputation for competence and integrity ... the image of the Japanese bureaucrat was one of a man of ability and dedication who had forgone opportunities for material gain to serve the nation.' 
scandals proved to be only the tip of the iceberg, as it emerged that many more Ministry of Finance officials had allegedly accepted illicit 'entertainment' provided by private financial institutions (Brown 1999; Kaneko 1999).

Another scandal was the 'jusen bailout' during 1995 and 1996, in which the Ministry of Finance made the highly contentious decision to use taxpayers' money to bail out many jusen (loan companies) that had become bankrupt through ill-advised decisions during the bubble years (Inoguchi 1997). This was an example of both policy failure and serious misconduct. Inoguchi (1997) suggests that this preferential decision can be explained in part by the fact that these jusen were popular destinations for amakudari (literally 'descending from heaven') - career civil servants who move to the private sector after retirement. Not only were the prestige and reputation of the bureaucracy diminished following the jusen scandal, but also there were indications that their actual power decreased.

Another practice that regularly caused public outrage was that of kankansettai: the wining and dining of officials from the central bureaucracy by their counterparts in local government. The latter have always claimed that if they did not entertain central bureaucrats, they would not receive the necessary information and appropriate funding from the Central Government (Inoguchi 1997).

In short, all these scandals have their roots in the traditional values and practices of the public service. Although the Japanese public service continued to value its prestige as well as its competence-and, on occasions, even claimed a 'high morality' - some of its practices were no longer acceptable in the light of modern global standards. The private sector would naturally engage in wining and dining to help foster better relationships, but many public servants were not aware that such practices could be seen as a bribe. Similarly, gift-giving is a traditional cultural practice showing respect and gratitude and is not necessarily connected to a specific interest. Nevertheless, many still have difficulty understanding that gift-giving can cause problems not only for the givers but also for the recipients. Traditional practices thus clash with the adoption of new ethical standards designed precisely to prohibit many of these traditions, but which may leave officials feeling that by not doing these things their counterparts will consider them to be lacking politeness and respect. 
The introduction of modern ethical management into the bureaucracy was triggered by three notable events. First, after the 'recruit scandal' surfaced, the Cabinet made a decision- 'Regarding the Enforcement of Official Discipline' (December 1988) - stating that government officials should refrain from acts that could invite public suspicion. Second, following the wave of scandals in the mid-1990s, the Council of ViceMinisters reached an agreement in 1996 requiring each ministry to establish its own code of conduct for contact with people or entities from the private sector or from other public organisations whose interests are affected by the decisions of public servants. Those who violated the code could be reprimanded under the National Public Service Law (Kaneko 1999). The council also provided a model code for ministries. Despite these efforts, the scandals continued, leading Hashimoto to establish a committee to draft guidelines for service-wide ethical behaviour in 1998. The Ethics Law was finally promulgated on 13 August 1999 (Japanese Government 1999). It prescribed a systemwide code to replace the individual codes of the ministries (Goda 2001; Japanese Government 2000).

\section{Political and administrative reform, 1990s-2000s}

In the 1990s, faced with growing economic problems and the gradual unravelling of the 1955 Japan Inc. regime, there emerged a vibrant discourse among the elite in favour of political reform. In 1993, the government of Morihiro Hosokawa was formed from an alliance of eight separate political parties. This government was the first not to include the LDP since the establishment of the ' 1955 system'. Hosokawa had an ambitious reform plan that included restrictions on donations to political parties, increased public subsidies for parties, harsher penalties for corruption and proposals for electoral reform. ${ }^{5}$ However, the government lasted only until April 1994, having achieved only part of its electoral reform agenda. Under the reformed electoral system, 200 members of the lower house would be elected in 11 regional districts under proportional representation and 300 in single-member districts, in place of the traditional multimember districts that had been blamed for pork-barrelling behaviour (Stockwin 1997a).

5 A law was introduced only in November 2000, prescribing penal sanctions for Diet members and members of local assemblies if they received financial gain in return for efforts to influence the awarding of contracts or administrative positions. 
One of the preoccupations of administrative reform from the 1990s has been to reduce the size of government in terms of both cost and staff. This history of downsizing has today produced a country with both a government and a public administration system that are the smallest among industrialised democracies. In the 1960s and again in the 1980s the Provisional Commission for Administrative Reform (PCAR) made significant cutbacks and devolved power to local governments. Furthermore, it delegated power to public corporations in the 1960s and undertook a program of privatisation in the 1980s (Furukawa 1999; Masujima and O'uchi 1995). ${ }^{6}$

The main administrative reform of the 1990s was initiated by prime minister Hashimoto, who ranked this goal as his government's top priority. As a result, administrative reform was driven by two developments mentioned above: increasing scepticism over the integrity of the bureaucracy because of its policy failures and misconduct, and widespread calls for drastic economic reform that would also involve administrative reform (Mishima 1998: 969-70). Hashimoto also promised to reduce the number of government personnel by at least 10 per cent over 10 years.

The reform package initiated by the Hashimoto government and implemented under prime minister Keizō Obuchi after 1998 went further than simple cutbacks. First, in line with the new public management movement, the Japanese legislature, the Diet, approved the Policy Evaluation Act in 2001, which introduced a performance management system (Kudo 2002, 2003). The Act was inspired by the US Government's Government Performance and Results Act of 1993; however, it is more decentralised than the US version and gives more freedom to ministries and agencies to organise their own systems of evaluation (Yamamoto 2003). Second, the government reorganised and consolidated the national bureaucracy. One office (the Office of the Prime Minister) and 22 ministries and agencies became one office (the Cabinet Office) and 12 ministries and agencies. This reorganisation

6 The first significant administrative reform initiated by prime minister Yasuhiro Nakasone in the mid-1980s was characterised by Thatcherism and Reaganomics; Japanese reform was not an exception to these trends. The main strategy included privatisation and deregulation. In fact, Nakasone successfully privatised the national railway, the public telecommunications company and various public monopolies. This reform was remarkable not only for its success, but also for the fact that it fully introduced the global trend of public sector reform to traditional Japanese public administration. 
was enacted in 1998 and came into effect in 2001. These changes forced wideranging institutional and managerial transitions in the bureaucracy.

\section{Political and administrative reform, 2000 - present}

The brief overview provided above shows how Japan's stable and economically successful postwar political system began unravelling in the last quarter of the twentieth century (Jain and Inoguchi 1997). The historical model suggests that the elite bureaucracy provided concrete policy ideas to the ruling LDP, which delivered the plans and laws, enabling industry to grow consistently (until the end of the boom). This, in turn, gave financial resources back to the party. Industry continued to lobby ministries and agencies. Many bureaucrats-turned-politicians provided the necessary knowledge and expertise to move into politics; bureaucrats-turned-executives provided necessary links and information to industry. Business helped deliver votes to politicians; meanwhile, the bureaucracy and politicians provided incentives, subsidies and protection to business. This cosy arrangement prevailed throughout the postwar boom.

Then, in more recent decades, the economy stagnated and the 'iron triangle' model began to dissipate. The key features of the decline were: the reduction of the bureaucracy's power and prestige; an increasingly unpredictable and concerned electorate that became less tolerant of corruption; and the failure of governments to capitalise on the initially strong desire for reform (Campbell 1999). This decline influenced the policy agenda, which consisted of newly proposed reforms aiming to introduce 'global standards'. Eventually, a number of scandals acted as catalysts for moving reform proposals up the government's policy agenda (but see Black 2004).

The LDP government managed to survive until 2009, but only towards the end of its term did it announce plans for civil service reform. The Japanese Government began to realise there was an urgent need for structural reform, especially in its public administration, because of the nation's existing fiscal problems and rapidly changing demographics. It was conscious that Japan had a shrinking population and an ageing society, and yet had amassed a large public debt. Hence, the government announced its intention to reduce the total number of civil servants gradually over the course of a decade. In particular, 
the administration of Junichirō Koizumi (2001-06) and the succeeding LDP administrations drew up plans for civil service reform, declaring the total number of civil servants would be halved in 10 years. The reform, however, was implemented only slowly.

The demise of the LDP and the election of the Democratic Party of Japan (DPJ) as Japan's government in 2009 changed the traditional relationship between politics and bureaucracy, perhaps forever. Suddenly, the number of political appointments made by the government increased; accordingly, the political leadership of the DPJ was able to rule with greater authority. The DPJ government then made radical changes to many aspects of the civil service, including its selection processes, training requirements, leadership development and management practices. A major public service reform plan was submitted to the Diet on 3 June 2011, but was long left undiscussed in the Diet, due to other priorities, including the reconstruction plan following the Great East Japan Earthquake of the same year. There was a consensus among the main political parties on the future direction of the civil service, including the need for salary reductions, improvement of working conditions, establishment of a new management organisation for the civil service and the development of new talent to manage a range of new problems. Due to the dissolution of the House of Representatives on 16 November 2012, however, the proposal was scrapped.

After winning the 16 December 2012 election, the LDP restarted discussions of the reform plan and submitted a renewed version, which included the establishment of the Cabinet Bureau of Personnel Affairs, to the Diet on 5 November 2013. The amendment was enacted on 11 April 2014 after a long and difficult debate (Japanese Government 2014).

Meanwhile, relations between national and local government bureaucracies changed markedly. Many public services once delivered by local governments were now being delivered by private providers and non-governmental organisations. This meant that the functions of both national and local public servants changed: the role of public servants in local government shifted away from that of a direct provider to one of service coordinator, and the competencies required of national public servants changed from legally oriented to economic and technology oriented. At the national level, what are now required include stronger leadership, greater innovation and creativity in managerial skills, language knowledge and facilitation 
and coordination abilities. These changes require more adequate recruitment systems to select suitable candidates and to innovate training content and style.

\section{Current structure and composition of the Japanese Civil Service}

Although Japanese governments have always accused the civil service of being too big, it remains the smallest among OECD countries. In fact, when comparing the number of public employees with the population, Japan has 36.4 public servants per 1,000 citizens when the defence forces are included and only 34.3 if the figure is limited to administrative personnel. In comparison, the United Kingdom has 74.8 public servants per 1,000 citizens ( 71 for administrative personnel only), France has 88.7 per 1,000 citizens ( 84.2 for administrative personnel only) and the United States has a ratio of 65.5 per 1,000 citizens (58.6 for administrative personnel only). ${ }^{7}$

The total number of national public employees in Japan is 641,000 , which constitutes around 18.9 per cent of the total of 3,384,000; local public employees make up 81.1 per cent (about $2,744,000$ ). Of national public employees, about 342,000 (or 53.4 per cent) are classified as 'regular service' and about 298,000 (or 46.6 per cent) as 'special service'; the latter include ministers, vice-ministers, ambassadors and so on (approximately 500), as well as judges and court staff (about 26,000), Members of Parliament and their staff (about 4,000) and the defence forces (about 268,000).

The majority of the first category of 'regular service' civil servants operates under a system of pay and conditions imposed by the National Personnel Authority (NPA). Those under the NPA scheme are subject to the Remuneration Law and constitute 275,000 in total (42.9 per cent of all national public employees), which include: general office workers (approximately 152,000); diplomats (about 5,400); tax office workers (about 52,600); imperial, prison and coast guards (about 46,900); air traffic controllers, patent office examiners, and so on (about 7,700 ); doctors, nurses, pharmacists and other health workers (about 3,000); and researchers (about 1,500). There is a small portion of regular service public employees who are not subject to

7 Based on 2013 data for Japan and 2012 data the United Kingdom, France and the United States (NPA 2015a). 
the Remuneration Law, including prosecutors (approximately 2,600), national forest employees (about 4,700) and employees of Specified Incorporated Administrative Agencies (about 64,900). ${ }^{8}$

The NPA is also in charge of recruitment, human resource management (HRM), career design, skills and training, and capacity building of civil servants who belong to its pay scheme. Other institutions have their own HRM systems, training and capacity-building systems. For example, the Ministry of Defence has established its own HRM scheme, which is different to that of the NPA, and has its own National Defence Academy and other educational and training institutions. Since its establishment on 30 May 2014, the Cabinet Bureau of Personnel Affairs has been in charge of the HRM of top managers, the government's general HRM policy and its management and revision (Japanese Government 2014).

Among national public employees, there are three levels of career path, and each commences with its own recruitment examinations. Table 5.1 shows the recruitment examination results for these three categories in the 2014 financial year. Numbers within parentheses indicate female recruits. As can be seen from the table, the pass rate for each level is very low, implying high standards are expected.

Table 5.1: Recruitment numbers for the national civil service, 2014

\begin{tabular}{|l|c|c|c|}
\hline Type of examination & $\begin{array}{c}\text { Number of } \\
\text { applicants }\end{array}$ & $\begin{array}{c}\text { Number of } \\
\text { successful } \\
\text { candidates }\end{array}$ & $\begin{array}{c}\text { Number of } \\
\text { applicants } \\
\text { employed }\end{array}$ \\
\hline Career-track position & $\begin{array}{c}23,947 \\
(7,105)\end{array}$ & $\begin{array}{c}2,080 \\
(441)\end{array}$ & $\begin{array}{c}651 \\
(231)\end{array}$ \\
\hline Staff position (bachelor level) & 35,508 & 6.183 & 2,734 \\
& $(11,178)$ & $(1,741)$ & $(824)$ \\
\hline Staff position (high school diploma level) & 12,482 & 1,902 & 846 \\
& $(3,777)$ & $(602)$ & $(309)$ \\
\hline Others (bachelor level) & 35,693 & 4,339 & 1,753 \\
& $(10,855)$ & $(1,455)$ & $(550)$ \\
\hline Others (high school diploma level) & 32,343 & 4,190 & 1,738 \\
& $(6,393)$ & $(1,027)$ & $(417)$ \\
\hline
\end{tabular}

Source: NPA (2015b).

8 These numbers were published by the Cabinet Bureau of Personnel Affairs on 1 July 2015, with the exception of that for the Specified Incorporated Administrative Agencies, which was published on 1 January 2014. The latter was renamed the Agencies Engaged in Administrative Execution in April 2015. 
The figures show there are comparatively few so-called career civil servants, or 'fast streamers' as they are known. However, these recruits are more likely than those of other levels to go on to become senior managers. The number of female employed applicants has increased dramatically in the past two decades, from 6.1 per cent in 1990 to 38.8 per cent in 2015. Nonetheless, a glass ceiling is still evident for women, with few reaching senior or even middle-management levels. Women form only 3.3 per cent of senior management (director level at headquarters and head level at regional offices) and 6.4 per cent of middle management (deputy director level at headquarters and division director level at regional offices). Of the unit chiefs (the first managerial position), female managers constitute 18.9 per cent, which is still much lower than the percentage of female staff at entry level. ${ }^{9}$ Considering the need to ultimately achieve gender equality, the government has developed a policy to increase female management to up to 5 per cent at director level and 10 per cent at deputy level by 2016. The government has been promoting events to attract female university students to the civil service, and the NPA has been placed in charge of proposing concrete measures to create the necessary conditions.

The rigid civil service career system has long been criticised in Japan. In response, the NPA changed the recruitment and career system in 2012. Instead of the previous three categories (Level I, Level II and Level III), new categories are divided into a career-track position and two staff positions (bachelor level and high school diploma level) with much more flexible career paths. There has also been longstanding criticism of the retirement age for civil servants. The current reform plan includes proposals to change the retirement age - and with it the typical career path - as well as the contracts of civil servants. Since the traditional practice of amakudari (whereby career civil servants move to the private sector after their early retirement - a practice that is in fact forced on them by the career structure) has come under scrutiny in recent times, the reform plan outlines a rise in the retirement age from 60 , at present, to 65 by $2025 .{ }^{10} \mathrm{~A}$ newly introduced 'reappointment

\section{As of 2013.}

10 These former top administrators often receive a significantly higher wage, which is some compensation for their relatively low wage as public servants compared with top positions in the private sector. At the same time, this practice allows the ministry to provide opportunities at the top for younger promising public servants. Through personal ties, this practice also allows for a smooth and better relationship between bureaucracy and business. 
system' has allowed retired personnel to stay in the public service on renewable contracts of up to one year. The number of reappointed staff between the ages of 60 and 65 is increasing drastically. In the 2014 financial year, 3,072 retirement-age staff were transferred to these temporary, renewable contracts. In accordance with these changes, life planning after retirement has become increasingly important and must complement career design during employees' time in the civil service.

\section{Human resource development in the Japanese Civil Service}

On-the-job training (OJT) has been the most important training style in Japan for both the public and the private sectors. As well as OJT, the NPA provides and coordinates various types of training for civil servants, including administrative training, training by position level and training for employees of local organisations. Furthermore, there are:

- long-term overseas fellowship programs that enable civil servants to attend foreign graduate schools

- short-term overseas fellowship programs that provide opportunities to work in foreign government agencies and/or international organisations

- domestic fellowship programs for study at Japanese graduate schools.

These systems of dispatching personnel for training also include a private sector training program. In this section, the nature of Japanese civil services training will be illustrated.

During the 2013 financial year, various ministries offered 32,491 training courses and seminars for 888,399 participants. The NPA offered 211 courses that were open to all ministries, in which 8,507 national civil servants participated. More than 90 per cent of the training courses are closed courses run within each ministry for their own staff and about 7 per cent are open to national civil servants from all ministries. About 70 per cent of the courses focus on specific content, about 60 per cent last between 20 and 40 hours (three days to one week) and approximately 20 per cent last between 41 and 80 hours 
(one to two weeks). About 20 per cent of courses are directed towards senior and middle management and one-quarter of all participants were managers, although the low participation of senior managers is an issue.

Courses differ in their style of operation: half are day courses and another half use retreats, at least in part. The number of e-learning or correspondence courses has increased in recent years, although they still make up only a small percentage of all courses. Almost all courses conduct participant evaluation or feedback to check the effectiveness of the training and improve the content. The total cost for national civil service training in 2009 was $¥ 9.07$ billion (A $\$ 122$ million), which is $¥ 12,000$ ( $\mathrm{A} \$ 148$ ) per participant. These figures have been declining since 2004 .

\section{National Personnel Authority training}

The major components of training courses are provided by the NPA. The institute's training spectrum ranges from recruitment to HRM. It also deals with ethical issues as well as complaints from staff. The NPA provides joint training for senior personnel of all government sectors and ministries. As described in the NPA's Guide to Public Administration Training (2015c), the purpose of this training is, through training courses and the exchange of ideas between trainees:

[T]o enhance qualities and skills of personnel necessary for implementing relevant government measures and policies-from a broad perspective, with a flexible mind-set, great sensitivity and high ethical standards, and with well-developed international awareness, maintaining a national scope ... through discussion and experience working together, to deepen mutual understanding and reliance between participants ... [and] through all training courses, to strengthen a sense of mission as a servant for the whole nation, transcending the frames of government sectors and ministries. (NPA 2015c: 2)

In the 2010 financial year, the training courses offered by the NPA changed drastically, and it began to offer a greater number of shorter courses and established new leadership empowerment courses. The last started as a pilot project in the 2010 financial year, and was developed and incorporated into the civil service training program 
in the 2011 financial year. These changes are part of proposals recommended to the NPA by the Committee for Public Officers' Training and Capacity Building, ${ }^{11}$ which met regularly between June 2008 and March 2009 (coincidentally at the same time as the Expert Meeting for Reconsidering Recruitment and Examination). Based on these experiences, this section aims to explain the changing conditions of the Japanese Civil Service and corresponding efforts to provide capable personnel to cope with the new challenges facing Japanese society.

In 2012 the recruitment and selection procedures for national civil servants changed drastically - also as a result of the Expert Meeting's recommendations ${ }^{12}$ - and the new training programs were designed to accommodate these changes. Three principles guide the new training:

1. mutual enlightenment, which centres on a 'participation-oriented curriculum' that places emphasis on group discussion and exchange of opinions relating to policy issues and specific measures of each government sector and ministry

2. a wide variety of exchange between different areas, encouraging broader points of view through 'knowledgeable lecturers capable of discussing up-to-date topics, and demonstrating an awareness of problems' (NPA 2015c: 2)

3. participant-oriented training, conducted through 'retreat training at a facility distant from the workplace to facilitate multifaceted exchange and mutual understanding ... discussions with fresh and flexible ideas, and with an open mind' and a 'relationship of mutual trust developed through the free exchange of opinions and communication in and out of training courses' (NPA 2015c: 2).

The annual courses given by the NPA vary in their duration, objectives and content. ${ }^{13}$ Of these 14 courses, numbers 13 and 14 are designed for senior managers, courses 4-9 are for middle management and courses 1-3 for future managers. Courses 10-12 are for middle managers appointed through the Staff Position Examination (former Level II and III), and open up their chances of reaching a senior

\footnotetext{
11 See the section 'Civil service reforms' in this chapter.

12 Ibid.

13 These courses are the result of modifications started in the 2010 financial year and completed in the 2011 financial year. Further adjustments were conducted in 2013 after the recruitment and examination system was changed in 2012 .
} 
management level. The courses were strengthened in 2014 when Law No. 22 of 2014 (18 April) amended the law covering national public servants and introduced a system of training for executive candidates. Courses for senior and middle management tend to feature longer discussions than the other courses and stress the importance of studying the classics. In fact, many of them have workshops on classical literature and problem solving, rather than lectures on specific topics and methods. There are also workshops on facilitation, negotiation and team building.

1. Joint Initial Training: This three-day course is for new employees who are likely to engage in operations such as policy planning at headquarters in the future (employees newly appointed to government positions in the second grade of the Salary Schedule for Administrative Service I, including its equivalent) in conjunction with the Ministry of Internal Affairs and Communications. It is held once a year and trained 721 participants over three days in a retreat setting in 2014.

2. Initial Administrative Training: This course is for employees who participated in the Joint Initial Training. It is held four times a year and lasts for five weeks in a combination of retreat and daylong formats. In 2014, 608 employees were trained in five courses, as there was an increase in appointments for that year.

3. Third Year Follow-up Training: This is for employees who, in principle, participated in the Initial Administrative Training, are in their third year of administrative service and are likely to engage in operations such as policy planning at headquarters. It is held four times a year over four days, in a retreat setting, and trains about 120 participants per course, totalling 477 in 2014.

4. Administrative Training (Deputy Director Level): The NPA offers seven courses of three-day or four-day training targeting personnel at assistant director level at headquarters in charge of operations such as policy planning and who have been promoted to this level in the past year. Since 2010, this training has been reduced from eight days (three-day in-office and five-day retreat) to three days (five courses for retreat and two courses for commuting) so that all employees recently appointed as assistant directors can participate. As it is not easy to engage participants in deep group-based discussion, policy proposal and analysis in a threeday program, two four-day courses, which are more effective 
for deepening the participants' analytical skills, were launched in 2013. This course trains about 50 participants per session (386 in 2014).

5. Administrative Training (Deputy Director Level)International Course: After a trial in 2012, this course was fully implemented in 2013. The course aims to help participants enhance their communication and persuasive skills in English through presentation and discussions in English with the aim of developing human resources who can respond to the globalisation of public administration in each field. A combination of commuting and retreat, the course trained 42 people in 2014.

6. Administrative Training (Deputy Director Level)-Female Manager Training Course: This course was launched on a trial basis to exchange ideas with female leaders in the public and private sectors and to consider their leadership, management of subordinates and working style, targeting female employees who are likely to be responsible for administrative management at headquarters in the near future and will become role models for future female personnel. In 2014, 19 women attended this course.

7. Administrative Training (Deputy Director Level)—Dispatch Training to the Republic of Korea Central Official Training Institute and Dispatch Training Course to Republic of the Philippines: The NPA has conducted dispatch training courses to the Republic of Korea since 2006, targeting personnel at the deputy director level at the headquarters of the Cabinet Office and ministries. This course organises visits to Korea's Central Officials Training Institute for national public employees with the aim of exchanging opinions between Japanese administrative officials and their Korean counterparts and studying the administrative situation in Korea. In addition, a visit to Philippine Government agencies was organised in 2014 and, in 2013, the course visited Singapore. There were 24 participants in 2014.

8. Administrative Training (Deputy Director Level)Leadership Training: This course was launched in 2010 as a pilot project and then formally introduced in 2011. It is held once a year for 14 days (a combination of retreat and non-residential sessions), targeting officials at deputy director level at headquarters who are expected to play a central role as executive officials. There were 24 participants in 2014. 
9. Administrative Training (Director Level): This four-day course targets officials at director level at headquarters and is organised three times a year, one day of which includes a site visit. In 2014, 96 people participated in three courses.

10. Administrative Training (Special Course for Officer Level): This is two weeks of training for personnel who have been appointed through the Staff Position Examinations (former Level II and III) and will shortly be promoted to unit chief positions, and whom the Cabinet Office and each ministry are planning to foster as future executive officials or whose work performance is excellent enough for them to be considered as candidates for selection for a high-level position. Three courses in 2014 trained 105 participants.

11. Administrative Training (Special Course for Unit Chief Level): This two-week training course is for personnel at unit chief level at headquarters who have been appointed through the Staff Position Examinations (former Level II and III) and whom the Cabinet Office and each ministry are planning to foster as future executive officials. In 2014, one of the three courses was a commuting-style course to promote the participation of personnel who are busy with their work. Three courses trained 111 participants.

12. Administrative Training (Special Course for Deputy Director Level): These two two-week courses are for personnel at deputy director level at headquarters who have been appointed through the Staff Position Examinations (former Level II and III) and whom the Cabinet Office and each ministry are planning to foster as future executive officials. There were 64 participants in 2014.

13. Administrative Forum (Director Level and Executives at Headquarters): These are two-hour forums held in the evening at the NPA conference room to provide training opportunities for personnel at director level and above at headquarters so they can exchange opinions with intellectuals in various fields. Ten forums are conducted annually and there were 660 participants in 2014.

14. Administrative Seminar for Executives (Aspen Method): This four-day and three-night retreat seminar is designed for personnel at deputy director-general and lead director level at headquarters. It is thinking-based training that uses various classical works aimed at training for high-level leadership through mutual conversations among participants. This course also includes participants from private enterprise and foreign governments. 
During the 2014 financial year, 147 young civil servants attended foreign graduate schools, 26 were dispatched to foreign governments or international organisations, 17 entered domestic master's courses and five entered doctoral programs.

Furthermore, there are courses for specific topics, including courses: to improve participants' evaluation abilities; for newly recruited but experienced personnel; for mentoring; for female employees exclusively; and for learning personal management. There are additional training courses and seminars for basic skills and knowledge, including a course on civil service ethics and a course on manners. Courses have become shorter over the years to better complement the working lives of staff. In particular, the length of retreat courses is reducing and they are increasingly being replaced with non-residential courses.

\section{Training by other institutions}

There are also various specialised training courses offered by other institutions that are open to all national civil servants. For example, the Ministry of Internal Affairs and Communications conducts information security courses for various levels, as well as statistics courses, since it is responsible for the Japanese Bureau of Statistics. The Ministry of Foreign Affairs has its own training centre offering language and other specific courses, and outsources part of these courses to the Foundation for Advanced Studies on International Development (FASID), which organises courses related to project cycle management, development and aid, and evaluation of aid projects. The Ministry of Finance organises various open training courses for all national civil servants, while the Ministry of Education, Culture, Sports, Science and Technology offers specialised topical courses ranging from space development to nuclear energy.

There are also schools and training centres for specific categories of civil servant: the National Police Academy, the National Tax College, the Japan Coast Guard Academy and the Meteorological College, among others. These cover all levels of employee in their respective ministries.

For senior management, beyond courses at the NPA, there are opportunities to study abroad and to be seconded to international organisations or foreign governments. The number of senior managers 
with a master's degree and/or a doctorate from foreign institutions is increasing. Graduate schools and universities collaborate with the NPA to accept a small number of civil servants into their degree courses. Not many graduate schools and universities are directly involved in the civil service training; however, students from the law faculties and schools of traditional universities appear to form the best pool of candidates to succeed in the civil service entry examination. Students from public policy and public management schools are not as successful as students from traditional universities as their institutions have less than a decade of history and are still refining their teaching approach. The introduction of an examination category reserved for graduate school and law school graduates in 2012 was an attempt to change this situation. In 2014, law school graduates made up 45 per cent of the appointed graduate school candidates (administrative staff) and those from public policy schools 33.3 per cent. To diversify the skills of candidates and their ability to cope with global challenges, the political science and international politics examination will be drastically revised from 2016.

\section{Civil service reforms}

\section{Reform proposal for the recruitment and selection system}

The recruitment and selection procedure for national civil servants has changed since 2012 as a result of the recommendations made to the NPA by the Expert Meeting for Reconsidering Recruitment and Examination, which met between June 2008 and March 2009 and in which the author participated.

There are various factors that forced the government to reconsider the existing recruitment system. Five changes were made:

1. a full introduction of HRM based on ability and performance

2. a new examination system to guarantee diverse channels of recruitment

3. a new examination system to evaluate the planning skills of candidates 
4. new examination methods to evaluate candidates' logical thinking, application skills and planning and presentation abilities

5. fair and neutral examination.

The examination system that started in 2012 has many new aspects. There are four categories of examination:

1. to evaluate high policy planning ability among candidates with a master's degree

2. to evaluate the overall skills (similar to the existing examination) of candidates with bachelor degrees, high school diplomas or work experience

3. for specific jobs and functions

4. for experienced personnel recruited from the private sector (the National Public Employee Mid-Career Recruitment Examination).

To cope with social, economic and demographic changes, the civil service has to transform itself. A new recruitment system is required to guarantee that civil servants are sufficiently competent. The recruitment system has to deal with labour market as well as systemic changes, such as the introduction and establishment of law schools (graduate level) and Master of Public Management (MPM), Master of Public Policy (MPP) and Master of Public Administration (MPA) courses. This is why the NPA decided to introduce a new examination reserved specially for these graduate students, beginning in 2012 . So far, the number of employees choosing this examination is not significant, but it has been increasing and, more importantly, the success rate is much higher for this category compared with others, confirming the importance of these schools.

The existing mid-career recruitment examination guarantees mobility from the private to the public sector, as well as the recruitment of experts in a wide range of fields. The most important changes in this new system are the modification of examination content and evaluation methods. The new evaluation methods are targeted at recruiting creative and innovative personnel who are capable of logical thinking, policymaking, negotiating with others and building consensus. Thus, there will be evaluated discussion sessions in which the candidates are asked to solve problems or make policy proposals. 
Particular qualities, such as excellence in languages and expertise in strategic fields (including economics, finance and engineering), will be evaluated through various new channels. One of them is the midcareer recruitment examination.

Introducing more flexible career paths is also one of the objectives of this reform. Those who enter the civil service via Level II and Level III examinations will have more opportunities than before to rise through the ranks.

\section{Discussion and reform proposal for the civil service training system}

In the 2010 financial year, the training courses offered by the NPA were modified significantly to include more short courses and to introduce leadership empowerment courses. The latter started as a pilot project in 2010, and were fully introduced in 2011. Additional modifications were made in 2013 in line with the changes to recruitment and examination introduced in 2012. These changes are among the recommendations made to the NPA by the Committee for Public Officers' Training and Capacity Building, held between June 2008 and March 2009 - coincidentally, at the same time as the above-mentioned expert meeting. The author also took part in this committee.

The main issues identified in the committee's report were:

- the growing role and responsibilities of government

- the increasing frequency of scandals and policy failures

- the lack of general training to develop capable civil servants

- the growing need to provide public services efficiently and effectively

- the changing relationship between politics and the civil service.

The recommendations were as follows:

1. empower leadership, especially among senior managers

2. strengthen general capacity building

3. improve the ethical attitudes of tax managers and experts in other professional fields 
4. build the capacity of managers and public servants with a marketoriented mindset

5. serve the government faithfully

6. develop broad world views, problem-solving capacities and analytical skills in public servants.

The recommendations for new training methods submitted to the NPA were:

- to develop among employees an appreciation of the value of public service

- to instil in them a sense of mission and pride

- to maintain an adequate distance from politics

- to improve employees' problem-solving capacity through case analyses

- to build integrity and ethical thinking through the study of the classics.

The recommendations also refer to the establishment of a close relationship between recruitment, training and promotion through performance-based evaluation and performance-based HRM.

\section{Conclusion: How to cope with changing competencies through capacity building}

Economic recession, fiscal crisis, globalisation, an ageing and technology-driven society, an increasingly complex social structure, a changing relationship between politics and civil services and the establishment of public policy, public management and law graduate schools are all major factors that have forced the Japanese Civil Service to change its culture. The civil service has begun the process of reform by introducing a new recruiting system and changing its training program.

New civil servants are required to have competencies in policymaking, presentation, facilitation, negotiation, consensus building, innovative and creative thinking, logical thinking and leadership. To some extent, candidates are expected to possess these competencies before joining the civil service; however, such competencies are developed 
and extended through executive training. The type of training is also changing: traditionally highly regarded OJT has been replaced with specific training courses and capacity-building seminars.

Social and economic changes and civil service scandals accelerated the pace of the reform of the recruitment and training systems. The latter has been modified through pilot projects, enabling experimentation with various capacity-building theories.

It is too early to make any judgements about the success of the reform process; however, there is great optimism both within and outside the civil service. The first signs from the changing recruitment system have been positive: a more diverse set of candidates sat for the examinations, including more graduate students, and human resource personnel are utilising a greater range of selection processes. The attractiveness of the new recruitment, selection and training systems will draw a higher standard of candidates to the Japanese public service, despite the recent drawback of the civil service salary cut proposed by the current government.

\section{References}

Black, W. K. 2004. The Dango tango: Why corruption blocks real reform in Japan. Business Ethics Quarterly 14(5): 603-23.

Brown, J. R. 1999. The Ministry of Finance: Bureaucratic practices and the transformation of the Japanese economy. Westport, Conn.: Quorum Books.

Callon, S. 1995. Divided Sun: MITI and the breakdown of Japanese hightech industrial policy, 1975-1993. Redwood City, Calif.: Stanford University Press.

Campbell, J. C. 1999. Administrative reform as policy change and policy non-change. Social Science Japan Journal 2(2): 157-76.

Clesse, A., Inoguchi, T., Keehn, E. B. and Stockwin, J. A. A. 1997. The Vitality of Japan: Sources of national strength and weakness. Basingstoke, UK: Palgrave Macmillan.

Curtis, G. L. 1999. The Logic of Japanese Politics. New York: Columbia University Press. 
Furukawa, S. 1999. Political authority and bureaucratic resilience: Administrative reform in Japan. Public Management 1(3): 439-48.

Goda, H. 2001. Preparation and implementation of Japan's National Public Service Law. In OECD and ADB, Progress in the Fight against Corruption in Asia and the Pacific, 175-9. Seoul: OECD and ADB.

Hartcher, P. 1998. The ministry. How Japan's most powerful institution endangers world markets. Cambridge, Mass.: Harvard Business School Press.

Hayao, K. 1993. The Japanese Prime Minister and Public Policy. Pittsburgh: University of Pittsburgh Press.

Inoguchi, T. 1997. Japanese bureaucracy: Coping with new challenges. In P. Jain and T. Inoguchi (eds), Japanese Politics Today: Beyond karaoke democracy?, 92-107. Basingstoke: Palgrave Macmillan.

Inoguchi, T. (ed.) 2008. Human Beliefs and Values in Incredible Asia: South and Central Asia in focus-Country profiles and thematic analyses based on the Asia Barometer Survey of 2005. Tokyo: Akashi Shoten.

Inoguchi, T. 2009. Human Beliefs and Values in East and Southeast Asia in Transition: 13 country profiles on the basis of the Asia Barometer Survey of 2006 and 2007. Tokyo: Akashi Shoten.

Jain, P. and Inoguchi, T. (eds) 1997. Japanese Politics Today. Basingstoke, UK: Palgrave Macmillan.

Japanese Government 1999. National Public Service Ethics Law. Law No. 129 of 1999, 13 August. Japanese Government, Tokyo. Available from: japaneselawtranslation.go.jp/law/detail/?ft $=1 \& \mathrm{re}=01 \& \mathrm{dn}=1 \& \mathrm{co}=01 \& \mathrm{x}=0 \& \mathrm{y}=0 \& \mathrm{ky}=\% \mathrm{E} 5 \% 9 \mathrm{~B} \% \mathrm{BD} \% \mathrm{E} 5 \%$ AE $\%$ B6\%E5\% $\% 5 \%$ AC \% $5 \% 8 B \% 99 \%$ E5\%93\%A1\%E5\%80\% $\mathrm{AB} \% \mathrm{E} 7 \% 90 \% 86 \% \mathrm{E} 6 \% \mathrm{~B} 3 \%$ 95\&page $=1$ (accessed 2011).

Japanese Government 2000. National Public Service Officials Ethics Code. Cabinet Order No. 101 of 2000: 28 March. Tokyo: Japanese Government.

Japanese Government 2014. Law to Amend Part of the National Public Service Act. Law No. 22 of 2014: 11 April. Tokyo: Japanese Government. 
Kaneko, Y. 1999. History of unethical conduct and recent measures to raise ethical standards in the Government of Japan. Global Virtue Ethics Review 1(4): 266-82.

Kerbo, H. R. and McKinstry, J. A. 1995. Who Rules Japan? The inner circles of economic and political power. Westport, Conn.: Praeger.

Koh, B. C. 1989. Japan's Administrative Elite. Berkeley: University of California Press.

Kudo, H. 2002. Performance measurement for governance: From TQM to strategic management and programme budgeting. In D. Bräuning and P. Eichhorn (eds), Evaluation and Accounting Standards in Public Management, 94-103. Baden-Baden, Germany: Nomos Verlagsgesellschaft.

Kudo, H. 2003. Between the 'governance' model and the Policy Evaluation Act: New public management in Japan. International Review of Administrative Sciences 69(4): 483-504.

Kudo, H. 2009. Client-orientation for good governance vs. clientelism. The NISPAcee Journal of Public Administration and Policy 2(2): 89-96.

Kudo, H. 2010. E-government as strategy of public sector reform. Financial Accountability and Management 26(1): 65-84.

McVeigh, B. J. 1998. The Nature of the Japanese State: Rationality and rituality. Abingdon, UK: Routledge.

Masujima, T. and O'uchi, M. 1995. The Management and Reform of Japanese Governemnt. 2nd edn. London: Institute of Administrative Management.

Mishima, K. 1998. The changing relationship between Japan's LDP and the bureaucracy. Asian Survey 38(10): 968-85.

National Personnel Authority (NPA) 2000. Annual Report 1999. Tokyo: National Personnel Authority.

National Personnel Authority (NPA) 2001. Annual Report 2000. Tokyo: National Personnel Authority.

National Personnel Authority (NPA) 2010. Annual Report FY 2009. Tokyo: National Personnel Authority. 
National Personnel Authority (NPA) 2011. Annual Report FY 2010. Tokyo: National Personnel Authority.

National Personnel Authority (NPA) 2012. Annual Report FY 2011. Tokyo: National Personnel Authority.

National Personnel Authority (NPA) 2013. Annual Report FY 2012. Tokyo: National Personnel Authority.

National Personnel Authority (NPA) 2014. Annual Report FY 2013. Tokyo: National Personnel Authority.

National Personnel Authority (NPA) 2015a. 2015 Profile of National Public Employees in Japan. Tokyo: National Personnel Authority.

National Personnel Authority (NPA) 2015b. Annual Report FY 2014. Tokyo: National Personnel Authority.

National Personnel Authority (NPA) 2015c. Guide to Public Administration Training. Tokyo: National Personnel Authority.

Organisation for Economic Co-operation and Development (OECD) 2000. Trust in Government: Ethics measures in OECD countries. Paris: OECD.

Price, J. 1997. Japan Works: Power and paradox in postwar industrial relations. Ithaca, NY: ILR Press.

Richter, F. J. (ed.) 1996. The Dynamics of Japanese Organizations. Abingdon, UK: Routledge.

Stockwin, J. A. A. 1997a. Reforming Japanese politics: Highway of change or road to nowhere? In P. Jain and T. Inoguchi (eds), Japanese Politics Today, 75-91. Basingstoke, UK: Palgrave Macmillan.

Stockwin, J. A. A. 1997b. The need for reform in Japanese politics. In A. Clesse, T. Inoguchi, E. B. Keehn and J. A. A. Stockwin (eds), The Vitality of Japan: Sources of national strength and weakness, 91-111. Basingstoke, UK: Palgrave Macmillan.

Yamamoto, H. 2003. New Public Management: Japan's practice. Tokyo: Institute for International Policy Studies. 
This text is taken from Sharpening the Sword of State: Building executive capacities in the public services of the Asia-Pacific, edited by Andrew Podger and John Wanna, published 2016 by ANU Press, The Australian National University, Canberra, Australia. 